\title{
MASHLAHAH AL-MURSALAH SEBAGAI DALIL DAN METODE IJTIHAD
}

\author{
Isnaini \\ Universitas Islam Negeri Imam Bonjol Padang \\ isnainikhalil@gmail.com
}

\begin{abstract}
Mashlahah al-mursalah (consideration of public interest) is a part of mashlahah (public interest), functions as argument and method to formulate the law when no legal argument to do or not to do. There is a ulama consensus on the allowance to consider public interest as argument or ijtihad method. This article explores various problem dealing with, ranging from the terminology, etymology, various of it, the requirement of mashlahah al-mursalah, and mashlahah al-mursalah as argument and ijtihad method and the implementation of mashlahah al-mursalah in early period, contemporary and the future.
\end{abstract}

Keywords: Mashlahah al-Mmursalah; Argument; Method of Ijtihad

\begin{abstract}
Abstrak
Mashlahah al-mursalah adalah bahagian dari mashlahah, yang berfungsi menjadi dalil serta alat perumus hukum ketika tidak ada dalil hukum yang menyuruh atau melarang. Maka di sini terdapat ketidaksepakatan ulama tentang kebolehan berhujjah sebagai dalil dan metode ijtihad. Walaupun seperti itu, mashlahah mursalah telah memberikan solusi dalam menyelesaikan berbagai persoalan perbuatan manusia yang terkait hukum semenjak zaman Nabi Saw. sampai sekarang. Dalam artikel ini akan dipaparkan berbagai persoalan terkait dengan mashlahah al-mursalah, mulai terminology mashlahah al-mursalah dari sisi etimologi dan terminologi, macam-macam, syarat-syarat kehujjahan mashlahah al-mursalah, mashlahah al-mursalah sebagai dalil dan metode ijtihad dan perwujudan mashlahah al-mursalah di zaman klasik, kontemporer dan masa mendatang.
\end{abstract}

Kata Kunci: Mashlahah al-mursalah; Dalil; Metode ijtihad 


\section{PENDAHULUAN}

Mashlahah al-mursalah, yang dipahami sebagai kemaslahatan, tidak mendapat legalitas khusus dari nas tentang keberlakuan dan ketidakberlakuannya karena tidak ditemukan secara eksplisit pembahasannya dalam nas al-Qur'an maupun hadis, telah diterapkan sebagai dalil dan metode ijtihad jauh sebelum eranya al-Syâtibî yang dianggap sebagai bidannya maqasid al-syari'ah dalam kajian ushul fiqh. Sebagai parameternya adalah dengan melihat kemungkinan kemaslahatan dan kemafsadatan yang akan timbul, lalu ditarik kesimpulan hukum.

Mashlahah al-mursalah dianggap sebagai pertimbangan bagi agenda kemanusiaan dalam hukum, untuk memelihara lima hal pokok; agama, jiwa, akal, keturunan dan harta, atau disebut juga sebagai sifat yang melekat pada struktur hukum berupa upaya untuk mengambil hal positif dan meninggalkan yang negatif bagi manusia. Penempatan mashlahah al-mursalah sebagai dalil dan metode ijtihad atau sebagai metode istinbât hukum, menampakkan keluwesan dan keuniversalan hukum Islam. Ini dapat diartikan bahwa hukum Islam dapat diterapkan pada setiap ruang dan waktu di segala bidang sosial.

Dalam artikel akan dipaparkan berbagai persoalan terkait dengan mashlahah almursalah, mulai terminology mashlahah al-mursalah dari sisi etimologi dan terminologi, macam-macam, syarat-syarat kehujjahan mashlahah al-mursalah, mashlahah al-mursalah sebagai dalil dan metode ijtihad dan perwujudan mashlahah al-mursalah di zaman klasik, kontemporer dan masa mendatang.

\section{METODE}

Penelitian ini termasuk jenis penelitian kualitatif karena data-data yang digunakan adalah non angka sedangkan penggolongan yang lain penelitian ini termasuk penelitian studi kepustakaan (library research) karena sumber data yang digunakan murni dari karyakarya pustaka baik berupa kitab, buku, jurnal, dan lain-lain, atau bisa juga digolongkan pada kelompok jenis penelitian pemikiran fuqaha. ${ }^{1}$

Adapun pendekatan yang digunakan dalam penelitian ini adalah pendekatan filosofis logis. Sebab, penggunaan mashlahah al-mursalah sebagai dalil dan metode ijtihad masih terdapat pro dan kontra di kalangan kaum muslimin sendiri, sehingga untuk memahaminya diperlukan pendekan filosofis logis.

${ }^{1}$ Cik Hasan Bisri, Model Penelitian Fiqih: Paradigma Penelitian Fiqh \&bFiqh Penelitian, (Jakarta: Prenada Media, 2003), Cet. I, h. 139-288. 


\section{PEMBAHASAN}

\section{Pengertian Mashalahah}

Sebelum menjelaskan terminologi dari sisi mashlahah mursalah, perlu dibahas lebih dahulu dari sisi rangkaian kata mashlahah, karena mashlahah al-mursalah itu merupakan salah bentuk dari mashlahah. Mashalahah (صصلحة) berasal dari shalaha (صلح), secara arti kata berarti baik lawan dari buruk. Ia adalah mashdar dengan arti kata shala>h (صلاح) yaitu manfaat atau terlepas dari padanya kerusakan. Ia juga berarti faedah, kepentingan, kemanfaatan dan kemaslahatan. ${ }^{2}$

Pengertian mashlahah dalam bahasa Arab berarti perbuatan-perbuatan yang meransang kepada kebaikan umat manusia. Dalam arti umum adalah setiap segala yang memberi kemanfaatan bagi manusia, baik dalam arti menarik atau menghasilkan seperti menghasilkan keuntungan atau kesenangan atau dalam arti menolak atau menghindarkan seperti menolak kemudaharatan atau kerusakan. Jadi setiap yang mengandung manfaat patut disebut mashlahah. Dengan begitu mashlahah itu mengandung dua dimensi yaitu menarik atau mendatangkan kemashlahatan atau menolak atau menghindarkan kemudharatan. ${ }^{3}$

Dalam Kamus Besar Bahasa Indonesia dibedakan antara arti kata maslahat dengan kemaslahatan. Kata maslahat, menurut kamus tersebut, diterjemahkan dengan "sesuatu yang mendatangkan kebaikan, faedah dan guna”. Sedangkan kata kemaslahatan memberi makna "kegunaan, kebaikan, manfaat dan kepentingan". Dari sudut ini jelaslah bahwa Kamus Besar Bahasa Indonesia memandang bahwa kata maslahat dikategorikan sebagai sebuah kata dasar, sedangkan kata kemaslahatan dikategorikankan sebagai kata benda jadian yang berasal dari kata maslahat yang mendapatkan awalan ke dan akhiran an. ${ }^{4}$

Dalam memahami mashlahah secara terminologi terdapat perbedaan rumusan di kalangan ulama, namun kalau dianalisis bermuara hakikat yang sama. Di bawah ini akan dipaparkan beberapa terminology antara lain:

1. Alghazali menjelaskan bahwa menurut asalnya mashlahah itu berarti sesuatu yang mendatangkan hakikat dari mashlahah dengan defenisi sebagai berikut:

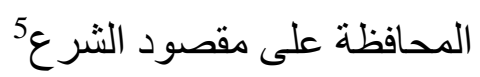

\footnotetext{
${ }^{2}$ Ahmad Warson Munawwir, Kamus Arab Indonesia Terlengkap, (Surabaya: Pustaka Progressif, 1997), h. 788789.

${ }^{3}$ Amir Syarif uddin, Ushul Fiqh Jilid 2, (Jakarta: Kencana Prenada Media Group, 2014), h. 388.

${ }^{4}$ Departemen Pendidikan dan Kebudayaan, Kamus Besar Bahasa Indonesia (Jakarta: Balai Pustaka, 1996), cet. Ke-2, h. 634.

${ }^{5}$ Abu Ha >mid Al-ghazali, Al-mustashfa min 'ilm Al-ushul, (Beirut: Dar Al-ma'a>rifah, 1993), jilid 2, h. 483.
} 
2. Al'iez Abd Al-salam dalam kitab Qawa'id Al-ahkam menarasikan arti mashlahah dalam bentuk hakikinya yakni“kesenangan dan kenikmatan”. Sedangkan bentuk dalam tataran majaz adalah "sebab-sebab yang mendatangkan kesenangan dan kenikmatan". Arti ini didasarkan kepada empat prinsip bentuk manfaat, yaitu kelezatan dan sebab-sebab serta kesenangan dan sebab-sebabnya. ${ }^{6}$

3. Al-syathibi merumuskan mashlahah itu dari dua pandangan yaitu dari segi terjadinya mashlahah itu dalam kenyataan dan dari segi tergantungnya tuntutan syara'kepada mashlahah.t.'

4. Dari segi tergantungnya tuntutan syara' kepada mashlahah yaitu kemashlahatan yang merupakan tujuan penetapan syara. Allah menuntut manusia berbuat agar mendapatkan kemashlahatan.

5. Al-thufi mengatakan dalam kitabnya al-Ta'yin fi Syarh al-Arba'in, sebagaimana yang dinukil oleh Yusuf Hamid Al-'alim dalam bukunya Al-maqashid al-'Ammah li Syari'ati al-Islamiyyah mendefenisikan mashlahah sebagai berikut:

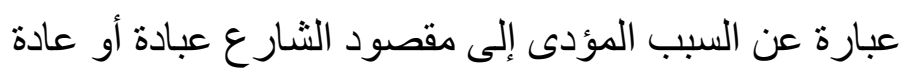

Artinya: Ungkapan dari sebab yang membawa kepada tujuan syarak dalam bentuk ibadat atau 'adat.

Defenisi Al-thufi ini bersesuaian dengan defenisi Al-ghazali yang memandang mashlahah dalam artian syara' sebagai sesuatu yang dapat membawa kepada tujuan syara'. Beberapa defenisi tentang mashlahah dengan rumusan yang berbeda tersebut, dapat memberikan kesimpulan tentang esensi mashlahah itu, yakni sesuatu yang dipandang baik oleh akal sehat, karena mendatangkan kebaikan dan menghindarkan keburukan (kerusakan) bagi manusia, sejalan dengan tujuan syara' dalam menetapkan hukum.

Kesimpulan tersebut memperlihatkan adanya adanya ketidaksamaan pengertian mashlahah dalam tataran bahasa (umum) dibandingkan dengan mashlahah pada tataran pengertian hukum atau syara'. Ketidaksamaan pengertian itu kelihatan dari segi tujuan syara' yang dijadikan rujukan. Mashlahah dalam pengertian bahasa merujuk kepada tujuan pemenuhan kebutuhan manusia dan karenanya mengandung pengertian untuk mengikuti syahwat atau hawa nafsu. Sedangkan mashlahah dalam artian syara' yang menjadi titik

\footnotetext{
${ }^{6}$ Syaikh Al-isla $>$ my 'Izz Al-di $>$ n 'Abd - 'azi $>$ z bin 'Abd Al-sala $>$ m, Al-qawa $>$ 'id Al-kubra Al-ma'shu $>$ m bi Alqawa $>$ 'id Al-ahka $>m$ Fi Fi $>$ ishla $>h$ Al-ana $>m$ (Damaskus: Dar Al-qala $>$ m), h. 6-15.

${ }^{7}$ Abu Isha $>$ q Ibrahim bin $\mathrm{Mu}>$ sa Al-lakhmi Al-gharnathi Al-ma>liki, Al-muwa $>$ faqat fi Ushul Al-ushu $>1$ Alsyari'ah (Beirut: Dar Al-kutb Al-isla>miyyah, 2004).

${ }^{8}$ At-Thufi, al-Ta'ȳ n Fi Syarhi al-Arba'T n, (Beirut: Muassasah alRayyan, 1998), h. 239. Lihat juga Yusuf $\mathrm{Ha}>$ mid Al-'alim, Al-maqa>shid Al-'ammah li syari'ati Al-isla>miyyah, (Riyadh : Al-ma'had Al-'ala>my li al-fikr Alisla $>$ my, $1415 \mathrm{H} / 1994 \mathrm{M})$, h. 138
} 
bahasan dalam ushul fiqh, adalah tujuan syara' yaitu menjaga agama, jiwa, akal, keturunan dan harta benda, tanpa melepaskan tujuan pemenuhan kebutuhan manusia yaitu mendapatkan kesenangan dan menghindarkan ketidaksenangan (kesulitan). ${ }^{9}$

Yusuf dalam kitab Al-maqashid menjelaskan keistimewaan mashlahah sya>ri disbanding dengan mashlahah dalam artian umum, sebagai berikut ${ }^{10}$ :

a. Petunjuk syara' adalah sentral dari pedoman dari mashlahah itu, bukan semata bersumber akal manusia, karena adanya ketidaksempurnaan akal manusia itu sendiri, yang dipengaruhi sifat relatif dan subjektif, dibatasi ruang, waktu dan tempat serta bias pengaruh lingkungan dan dorongan hawa nafsu.

b. Pengertian mashlahah atau mafsadah dalam perspektif syara' tidak terbatas untuk kepentingan dunia semata, bahkan juga untuk akhirat, tidak hanya untuk kepentingan semusim, tetapi berlaku untuk sepanjang masa.

c. Mashlahah dalam terminology syara' tidak terbatas pada rasa enak atau tidak enak dalam fisik jasmani, tetapi juga dalam artian mental spiritual atau secara ruhaniyah.

Adapun dhawabith (standar) yang bisa diperlakukan kepada sesuatu itu bisa dijadikan hukum berdasarkan mashlahah al-mursalah adalah sebagai berikut ${ }^{11}$ :

1. Penerapan untuk terlaksananya maqashid syari'at yang lima kebutuhan manusia.

2. Tidak bertentangan dengan $\mathrm{Al}$-quran.

3. Tidak bertentangan Al-sunnah.

4. Tidak bertentangan dengan Al-qiyas.

5. Tidak mengalahkan mashlahat yang lebih utama.

\footnotetext{
${ }^{9}$ Amir Syarifuddin, Ushul Fiqh Jilid 2, (Jakarta: Kencana Prenada Media Group, 2014), h. 347.

${ }^{10}$ Yusuf Hamid al-'Alim, al-Maqashid al- 'Ammah li Syari'ati al-Isla>miyyah, (Riyadh: Al-Ma'had al-'Alamy li al-Fikr al-Islamy, 1415 H/1994 M), h. 138.

${ }^{11}$ Muhammad Sa'id Ramadhan al-Buthi, Dhwabith fi al-Syaria'h al-Isla>miyyah (Beirut: Muassasah Alrisa $>$ lah, 2001), h. 108-279. Lihat Fauzi, Al-Maslahah al-Syar'iyah Sebagai Sumber Hukum Islam, Kajian Kitab Dawabith al-Mashlahah Syeh Said Ramadan Buti, “Tribakti Jurnal Pemikiran Keislaman” Vol 27 No 2 (2016), h. 302-328. Al-Buthi berpandangan Standar dan karakteristik maslahah perpektif syariat Islam adalah berdimensi: mencakup dunia-akhirat, materi-ruhani, dan menjadikan agama sebagai maslahat utama. Sementara standar mashlahat barat cenderung duniawi dan meterialistik semata serta cenderung menjadikan agama sebagai alat untuk mewujutkan maslahat duniawi-materialistik tersebut.
} 


\section{Macam-macam Mashlahah}

Sebagaimana telah dijelaskan bahwa mashlahah dalam artian syara' bukan hanya didasarkan pada pertimbangan rasio semata dalam mempertimbangkan baik dan buruknya sesuatu, bukan pula karena dapat memberikan kenikmatan dan menghindarkan kerusakan , tetapi lebih jauh dari itu semua yaitu bahwa apa yang dipahami baik oleh akal juga harus sejalan dengan tujuan syara dalam menetapkan hukum, yaitu memelihara lima prinsip pokok kehidupan. Umpamanya rasio kenapa larangan itu ada dalam nash kerena mengandung unsur kebaikan dan kemashlahatan bahkan bisa menyelamatkan diri kita dari kerusakan akal dan mental. Hal ini telah sejalan dengan tujuan syara' dalam menetapkan haramnya minuman keras yaitu memelihara akal manusia, sebagai salah satu dari lima prinsip pokok kehidupan yang harus dipelihara.

Kekuatan mashlahah dapat dilihat dari segi tujuan syara' dalam menetapkan hukum yang berkaitan secara langsung atau tidak langsun dengan lima prinsip pokok kehidupan manusia yaitu mashlahah al-mursalah sebagai sebuah metode ijtihad agama, jiwa, akal, keturunan dan harta. Juga dapat dilihat dari segi tingkat kebutuhan dan tuntutan kehidupan manusia kepada lima hal tersebut.

1. Dari segi kekuatannya sebagai hujjah dalam menetapkan hukum, mashlahah ada tiga macam yaitu: mashlahah dharuriyyah, mashlahah hajiyah dan mashlahah tahsiniyah.

2. Dari segi adanya keserasian dan kesejalanan anggapan baik oleh akal itu dengan tujuan syaran' dalam menetapkan hukum, ditinjau dari maksud usaha mencari dan menetapkan hukum, mashlahah itu disebut juga munassib atau keserasian mashlahah dengan hukum Islam. Mashlahah dalam artian muna>sib itu dari segi pembuat hukum (syari') memperhatikan atau tidak, mashlahah terbagi kepada tiga yaitu mashalahah al-mu'tabarah, mashlahah al-mulghah dan mashlahah almursalah.

a. Mashalah al-mu'tabarah yaitu mashlahah al-mu'tabarah yaitu mashlahah yang diperhitungkan oleh syari' baik langsung maupun tidak langsung yang memberikan petunjuk pada adanya mashlahah yang menjadi alasan dalam menetapkah hukum. Dari langsung atau tidak langsungnya petunjuk (dalil) terhadap mashlahah tersebut. Mashlahah terbagi dua:

1) Munasib muatsir yaitu ada petunjuk langsung dari pembuat hukum (sya>ri') yang memperhatikan mashlahah tersebut. Contoh tidak mendekati wanita haid karena alasan penyakit. Hal ini disebut mashlahah karena menjauhkan diri dari kerusakan atau penyakit. Hal ini ditegaskan dalam QS. al-Baqarah (2): 222. 
2) Muna $>$ sib mula $>$ im yaitu tidak petunjuk langsung dari syara' baik dalam bentuk nash atau ijmak tentang perhatian syara' terhadap mashlahah tersebut, namun secara langsung tidak ada. Contoh bolehnya jamak shalat bagi orang yang muqim (penduduk setempat) karena hujan. Keadaan hujan ini memang tidak pernah dijadikan alasan untuk hukum jamak shalat, namun syara melalui ijmak menetapkan keadaan yang sejenis dengan hujan, yaitu dalam perjalanan (safar) menjadi alasan untuk bolehnya jamak shalat.

b. Mashlahah al-mulghah atau mashlahah yang ditolak, yaitu mashlahah yang dianggap baik oleh akal, tetapi tidak diperhatikan oleh syara' dan petunjuk syara' yang menolaknya. Seperti seorang raja atau orang kaya yang melakukan pelanggaran hukum, yaitu mencampuri isterinya di siang bulan Ramadhan. Untuk orang ini sanksi yang paling adalah disuruh dua bulan berturut-turut, karena cara inilah yang diperkirakan akan membuat jera melakukan. Pertimbangan ini memang baik dan masuk akal, bahkan sejalan dengan syari' dalam menetapkan hukum, yaitu menjerakan orang dalam melakukan pelanggaran. Namun apa yang dianggap baik oleh akal ini, ternyata tidak demikian menurut syari' bahkan ia menetapkan hukum yang berbeda dengan itu, yaitu harus memerdekakan hamba sahaya, meskipun sanksi ini bagi orang kaya atau raja dinilai kurang relevan untuk dapat membuatnya jera.

c. Mashlahah al-mursalah atau istihsan yaitu apa yang dipandang baik oleh akal sejalan dengan tujuan syara' dalam menetapkan hukum, namun tidak ada petunjuk syara' yang memperhitungkannya dan tidak pula petunjuk syara' menolaknya.

Jumhur ulama sepakat untuk mempergunakan mashlahah mu'tabarah, sebagaimana mereka juga sepakat dalam menolak mashlahah mulghah. Menggunakan metode mashlahah dalam berijtihad ini menjadi perbincangan yang berkepanjangan di kalangan ulama. Hal ini diuraikan berikut ini.

Namun Imam Al-ghazali membagi mashlahah kepada empat yakni ${ }^{12}$ :

1) Maslahah yang diterima nau'-nya oleh Syari' karena ada kemiripan nau' tersebut dengan ashal dan furu'.

${ }^{12}$ Abu Hamid Muhammad bin Muhammad al-Ghazali, al-Mustashfa min 'Ilm al-Ushul, Juz II, Dar al-Fikr, Kairo, 1937, h. 306. Lihat juga Noorwahidah, Noorwahidah. "Esensi al-mashlahah al-mursalah dalam teori istinbat hukum imam syafi' i.”Syariah Jurnal Hukum Dan Pemikiran, 2014. https:// doi.org/10.18592/syariah.v13i1. h. 88. 
2) Maslahah yang diterima jins-nya oleh Syari' karena ada kemiripan jins tersebut dengan ashl dan furu'. Maslahat ini sering disebut pula al-mashlahah almula> 'imah li jins tasharrufa>t asysyar'.

3) Maslahah yang berlawanan dengan syara' yang disebut dengan istilah almashlahah al-ba>thilah atau al-mashlahah al-mulghah.

4) Maslahat yang tidak disebut-sebut oleh syara', tidak ada nas yang mendukungnya, dan tidak ada pula nas yang menentangnya. Maslahat semacam ini disebut almashlahah al-gharibah.

\section{Mashlahah al-Mursalah}

Mashlahah al-mursalah terdiri dari dua kata yang hubungan keduanya dalam bentuk sifat dan maushuf atau dalam bentuk khusus yang menunjukan bahwa ia merupakan bahagian dari mashlahah. Tentang arti mashlahah telah dijelaskan di atas, secara etimilogis (bahasa) dan terminologis. Secara etimologi artinya "terlepas" atau dalam arti muthlaqah (bebas). Bila dikaitkan kata mursalah dengan mashlahah terlepas atau bebas dari keterangan yang menunjukan boleh atau tidak bolehnya dilakukan.

Ada beberapa ungkapan terminology yang bervariasi tentang mashlahah al-mursalah ini, namun masing-masing memiliki substansi pengertian:

1. Al-ghazali dalam kitab Al-mustasyfa memaparkan mashlahah mursalah sebagai berikut:

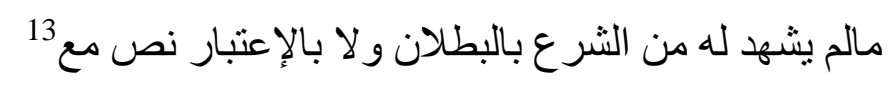

Artinya: Segala sesuatu yang tidak keterangan pada nash (hukum syara') yang menjelaskan pembatalan dan ada perhatian.

2. Al-syaukani dalam kitab Irsyad al-fuhu>l mwengungkapkan sebuah rumusan yakni:

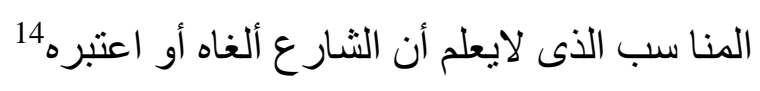

Mashlahah mursalah yang tidak diketahui dalil syara' yang menolak atau memperhitungkannya.

3. Abdul Wahab Khala $>$ f memberi terminology yakni:

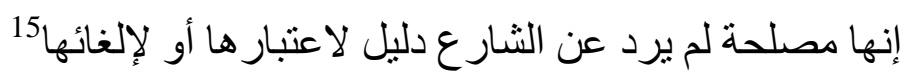

\footnotetext{
${ }^{13}$ Abu Hamida al-Ghazali, al-Mustashfa min 'Ilm al-Ushul, (Beirut: Dar al-Ma' arif, 1993), Jilid. 2, h. 481.

${ }^{14}$ Abu Hamid al-Ghazali, al-Mustashfa min 'Ilm al-Sshul h. 481.
} 
Mashlahah mursalah yang tidak ada dalil syara' datang mengakuinya atau menolaknya.

4. Muhammad Abu Zahrah memberikan defenisi yang hampir sama dengan rumusan Jala>1 Al-di>n yakni:

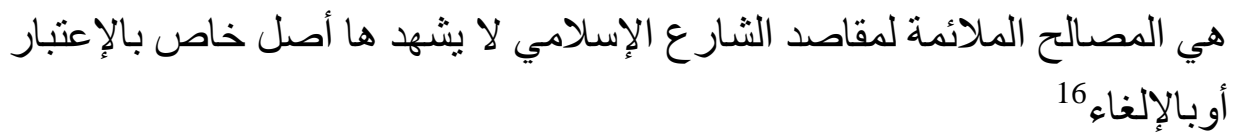

Mashlahah yang selaras dengan tujuan syari'at Islam dan tidak ada dalil syara' datang menolak atau memperhitungkan.

Beberapa rumusan di atas dapat ditarik kesimpulan bahwa mashlahah mursalah itu adalah sesuatu yang baik menurut akal, selaras dengan tujuan syara' serta tidak ada petunjuk syara' secara khusus yang menolak atau mengakuinya.

\section{Syarat-syarat Kehujjahan Mashlahah al-Mursalah}

Maslahah al-mursalah merupakan salah satu sumber hukum Islam yang kebenarannya masih terdapat khilafiyah di kalangan ulama. Para ulama sangat berhati-hati (ikhtiyath) dan memberikan syarat-syarat yang begitu ketat dalam mempergunakan maslahah mursalah sebagai hujjah, dengan alasan dikhawatirkan akan menjadi pintu masuk bagi pembentukan hukum syariat menurut hawa nafsu dan keinginan perorangan, bila tidak ada batasan-batasan yang benar dalam memperggunakannya. Oleh karena itu terdapat syarat-syarat maslahah mursalah sebagai dasar legislasi hukum Islam yang dikemukakan oleh ulama, diantaranya adalah:

1. Menurut Asy-Syatibi

Maslahah mursalah dapat dijadikan sebagai landasan hukum bila ${ }^{17}$ :

a. Kemaslahatan sesuai dengan prinsip-prinsip apa yang ada dalam ketentuan syari' yang secara ushul dan furu'nya tidak bertentangan dengan nash.

b. Kemaslahatan hanya dapat dikhususkan dan diaplikasikandalam bidang-bidang sosial (mu'amalah) di mana dalam bidang ini menerima terhadap rasionalitas dibandingkan dengan bidang ibadah. Karena dalam mu'amalah tidak diatur secara rinci dalam nash.

\footnotetext{
${ }^{15}$ Muhammad bin 'Ali al-Syaukani, Irsya $>d$ Al-fuhu $>1$ 'ila Thaqi $>q$ min 'ilm Al-ushu $>1$, (Riyadh: Dar alMa’arif , 2000), h. 995-989.

${ }^{16}$ Abdul Wahab Khala>f, Ushul Fiqh, (Kairo: Dar al-Qalam, 1978), h. 87.

${ }^{17} \mathrm{Abu}$ Ishaq Ibrahim bin $\mathrm{Mu}>$ sa al-Lakhmi al-Gharnathi al-Maliki, al-Muwa $>$ faqat fi Ushul al-Ushu>l alSyari'ah (Beirut: Dar al-Kutb al-Isla>miyyah, 2004).
} 
c. Hasil maslahah merupakan pemeliharaan terhadap aspek-aspek Daruriyyah, Hajjiyyah, dan Tahsiniyyah. Metode maslahah adalah sebagai langkah untuk menghilangkan kesu- litan dalam berbagai aspek kehidupan, terutama dalam masalah-masalah sosial kemasyarakatan (Asy-Syatibi, 1991).

2. Menurut Abdul Wahab Khallaf

Maslahah al-mursalah dapat dijadikan sebagai legislasi hukum Islam bila memenuhi syarat yang diantaranya adalah ${ }^{18}$ :

a. Berupa maslahah yang sebenarnya (secara haqiqi) bukan maslahah yang sifatnya dugaan, tetapi yang berdasarkan penelitian, kehati-hatian dan pembahasan mendalam serta benar-benar menarik manfa' at dan menolak kerusakan.

b. Berupa maslahah yang bersifat umum, bukan untuk kepentingan perorangan, tetapi untuk orang banyak.

c. Tidak bertentangan dengan hukum yang telah ditetapkan oleh nash (Alqur'an dan al- Hadits) serta ijma' ulama (Khallaf, 2002).

3. Menurut Al-Ghozali

Maslahah almursalah dapat dijadikan sebagai landasan hukum bila:

a. Maslahah mursalah aplikasinya sesuai dengan ketentuan syara'.

b. Maslahah mursalah tidak bertentangan dengan ketentuann nash syara' (Alqur'an dan al-Hadits).

c. Maslahah mursalah adalah sebagai tindakan yang dzaruri atau suatu kebutuhan yang mendesak sebagai kepentingan umum masyarakat (Jamil, 2008).

4. Menurut Jumhurul Ulama

Menurut Jumhurul Ulama bahwa maslahah mursalah dapat sebagai sumber legislasi hukum Islam bila memenuhi syarat sebagai berikut:

a. Maslahah tersebut haruslah "maslahah yang haqiqi" bukan hanya yang berdasarkan prasangka merupakan kemaslahatan yang nyata. Artinya bahwa membina hukum berdasarkan kemaslahatan yang benar-benar dapat membawa kemanfaatan dan menolak kemadharatan. Akan tetapi kalau hanya sekedar prasangka adanya kemanfaatan atau prasangka adanya penolakan terhadap kemazdaratan, maka pembinaan hokum semacam itu adalah berdasarkan wahm (prasangka) saja dan tidak berdasarkan syari' at yang benar.

\footnotetext{
${ }^{18}$ Khallaf, Abdullah Wahab. Ilmu Ushulul Fiqh. terj. Noer Iskandar al-Bansany. Kaidah-Kaidah Hukum Islam. Jakarta: PT. Raja Grafindo Persada, 2002).
} 
b. Kemaslahatan tersebut merupakan kemaslahatan yang umum, bukan kemaslahatan yang khusus baik untuk perseorangan atau kelompok tertentu, dikarenakan kemaslahatan tersebut harus bisa dimanfaatkan oleh orang banyak dan dapat menolak kemudaratan terhadap orang banyak pula.

c. Kemaslahatan tersebut tidak bertentangan dengan kemaslahatan yang terdapat dalam $\mathrm{Al}$-qur'an dan $\mathrm{Al}$-hadis baik secara dzahir atau batin. Oleh karena itu tidak dianggap suatu kemaslahatan yang kontradiktif dengan nash seperti menyamakan bagian anak laki-laki dengan perempuan dalam pembagian.

d.

\section{Mashlahah sebagai Dalil dan Metode Ijtihad}

Karena persoalan mashlah al-mursalah adalah dalil-dali yang dipertikaikan keberadaanya maka akan dipaparkan pandangan atau pendapat para ulama:

Mazhab Maliki, Hambali dan Al-Syathibi

Maslahah al-mursalah sebagai dalil dalam menetapkan hukum diterapkan oleh Ulama Ma>likiyah dan Hana>bilah, bahkan mereka diduga kuat sebagai ulama fiqh yang paling banyak dan luas mengimplementasikan. Dalam pandangan mereka maslahah al-mursalah merupakan induksi dari logika sejumlah nash, bukan dari nash yang terperinci seperti yang yang selama ini diterapkan dalam qiya>s. Bahkan Imam Sya thibi mengatakan bahwa eksistensi dan kualitas maslahah al- mursalah pada level pasti (qath’i), sekalipun dalam penerapannya bisa level zhanni (relatif)). ${ }^{19}$

Adapun faksi Malikiyyah dan Hanabilah, mereka banyak membentuk hukum berdasarkan maslahah al-mursalah semata, tanpa memasukkan ke dalam qiyas. Menurut Imam Malik, untuk menetapkan hukum berdasarkan dalil ini, ia mengajukan tiga syarat untuk maslahat agar bisa dijadikan sebagai dasar perumusan hukum, yaitu: Pertama, bahwa persoalan yang dikaji haruslah termasuk dalam ranah fiqh mu'amalah, sehingga kepentingan yang nampak di dalamnya dapat diukur berdasarkan penalaran kasus tersebut tidaklah boleh menyangkut segi ibadat. Kedua, bahwa kepentingan tersebut mestilah relevan dengan ruh syari'ah dan tidak boleh berbenturan dengan salah satu sumber hukum di dalamnya. 3. Ketiga, bahwa kepentingan tersebut haruslah sesuatu yang pokok dan darurat, bukan yang bersifat penyempurna (takmili). Hal-hal pokok tersebut mencakup tindakan memelihara agama, jiwa/kehidupan, akal, keturunan, dan kekayaan.

\footnotetext{
${ }^{19}$ Haroen, Nasrun. Ushul Fiqh. (Jakarta: Logos Wacana Ilmu, 2001), 85.
} 
Hal-hal yang darurat berhubungan dengan usaha untuk memperbaiki kehidupan, sedangkan hal-hal penyempurna bersifat hiasan, tambahan dan sekunder. ${ }^{20}$

Maslahah al-mursalah menurut Jumhur Ulama

Jumhur Ulama telah satu pendapat bahwa maslahah al-mursalah adalah merupakan dasar yang baik bagi dibentuknya hukum-hukum Islam. Hanya saja Jumhur Hana>fiyah dan Sya>fi'iyyah memberikan syarat tentang maslahah al-mursalah ini yakni posisinya hendaklah ia berada di bawah qiya >s, yaitu seandainya ditemukan hukum asal yang dapat dianalogikan kepadanya dan juga terdapat illat mundhabith (tepat). Sehingga dalam hubungan hukum itu terdapat tempat untuk mengwujutkan kemaslahatan. Berdasarkan pemikiran ini mereka berpegang pada kemalahatan yang direstui syara', tetapi mereka lebih leluasa dalam mengganggap maslahah yang dibenarkan syara' ini, karena luasnya mereka dalam soal pengakuan syari' (Allah) terdapat "illat sebagai tempat bergantungnya hukum, yang merealisir kemaslahatan. Sebab sebahagian besar maslahah al- mursalah yang tidak ada dalil yang menerima kebenarannya.

Pada tataran realita, dalam masalah ini, empat imam madzhab menerima substansi apa yang disebut maslahah. Hanya saja jumhur ulama Hanafiyah dan Syafi'iyah berupaya mengkategorikan maslahah ke dalam ruang lingkup qiyas. Mereka dalam masalah ini keras, demi memelihara hukum dan berhati-hati dalam soal perumusan hukum. Adapun golongan Malikiyah dan Hanabiyah, mereka menjadikannya sebagai dalil yang berdiri sendiri dengan nama maslahah mursalah. ${ }^{21}$

Najmuddin at-Thufi

At-Thufi berpendapat bahwa maslahah merupakan hujjah terkuat yang secara mandiri dapat dijadikan sebagai landasan hukum dan ia tidak membagi maslahat itu sebagaimana yang dilakukan oleh jumhur ulama. Ada tiga prinsip yang dianut Al-Thu>fi tentang maslahah yang menyebabkan pandangannya berbeda dengan jumhur ulama, yaitu:

a. Akal bebas menentukan kemaslahatan dan kemafsadatan khususnya dalam bidang mu'amalah dan adat ('urf). Untuk menen- tukannya termasuk mengenai kemaslahatan dan kemudharataan cukup dengan akal. Pandangan ini berbeda dengan jumhur ulama yang mengatakan bahwa sekalipun kemaslahatan dan kemudharatan itu dapat dicapai dengan akal, namun kemaslahatan itu harus mendapatkan dukungan dari nash atau ijma', baik bentuk, sifat maupun jenisnya.

\footnotetext{
${ }^{20}$ Syukur Sarmin, Sumber-sumber HukumIslam, (Surabaya: Al-Ikhlas, 1993), h. 73.

${ }^{21}$ Sarmin Syukur. Sumber-sumber HukumIslam (Surabaya: Al-Ikhlas, (1993).
} 
b. Maslahah merupakan dalil mandiri dalam menetapkan hukum. Oleh sebab itu, untuk kehujjahan maslahah tidak diperlukan dalil pendukung, karena maslahah itu didasarkan kepada pendapat akal semata.

c. Maslahah hanya berlaku dalam masalah mu'amalah dan adat kebiasaan, adapun dalam masalah ibadah atau ukuran-ukuran yang ditetapkan syara' tidak termasuk objek maslahah, seperti shalat dhuhur empat raka'at, puasa selama bulan ramadhan satu bulan dan lain-lain. Karena masalah-masalah seperti ini merupakan hak Allah semata.

Hasbi ash-Shiddieqy

Hasbi Ash-Shiddieqy berpendapat bahwa tidak ada perselisihan di kalangan ulama mengenai penetapan-penetapan hukum (tasyri) selama dimaksudkan untuk kemaslahatan manusia yang bersifat dharuriyat, hajiyat, maupun tahsiniyat. Adanya siyasah syar'iyyah, dalam bagian fiqh dikarenakan maksud hendak memberikan kemaslahatan, yakni kebijaksanaan untuk membuat masyarakat lebih dekat dan gemar kepada kebajikan serta menjauhi dan membenci keburukan dan kerusakan. Menurut ash-Shiddieqy, siyaasah syar'iyyah pada hakikatnya sama dengan maslahah mursalah. Maslahah mursalah inilah yang digali melalui qiyas, kaidah umum hukum dan istihsan. Selain itu, jumhur ulama pun sepakat, bahwa yang dinashkan oleh syara' yang didasarkan atas illat tujuannya adalah untuk mewujudkan kemas- lahatan bagi manusia. Ash-Shiddieqy berpendapat: "Berhujjah dengan maslahah mursalah dan membina hukum diatasnya, adalah satu keharusan. Inilah yang sesuai dengan keumuman syariat dan dengan demikianlah hukum-hukum Islam dapat berjalan beriringan dengan masa dan inilah yang ditempuh oleh para sahabat. Menolak maslahah mursalah berarti membekukan syariat, karena keragaman maslahat yang terus tumbuh tidak mudah didasarkan pada satu dalil tertentu”. Mencapai Maslahah juga merupakan salah satu tujuan syariah. ${ }^{22}$

1. Penerapan Mashlahah Al-mursalah di zaman klasik dan Kontemporer dan mendatang

Adapun contoh-contoh penggunaan maslahah mursalah antara lain:

a. Sahabat Utsman bin Affan menulis Al-quran kedalam beberapa mushaf. Padahal hal ini tak pernah dilakukan pada masa Rasulullah SAW. Alasan yang mendorong mereka malakukan pengumpulan pengumpulan itu tidak lain kecuali semata-mata maslahat, yaitu menjaga Al-Quran dari kepunahan atau

${ }^{22}$ Elvan Syaputra, Faridl Noor Hilal, Muhammad Febriansyah, Issa Qaed, Muhammad Majdy Amiruddin, Muhammad Ridhwan Ab. Aziz. "Maslahah as an Islamic Source and its Application in Financial Transactions". Journal of Research in Humanities and Social Science. Volume. 2. Issue 5, (2014). 
kehilangan kemutawatirannya karena meninggalnya sejumlah besar hafidz dari generasi sahabat. $^{23}$

b. Perbuatan para sahabat memilih dan mengangkat Abu Bakar ash-Shiddiq sebagai khalifah pertama pengganti Nabi Muhammad untuk memimpin ummat dalam rangka untuk meneruskan estafet kepemimpinan dan da'wah, serta menjaga, berlakunya syariat yang dibawa oleh Nabi. Pada saat itu, seorang khalifah sangat dibutuhkan, sehingga terpilihnya Abu Bakar merupakan suatu maslahat, walaupun hal tersebut tidak ditemukan dalil khusus dari teks syariat yang membenarkan atau menyuruh atau membatalkannya (melarang). ${ }^{24}$

c. Terbitnya fatwa-fatwa Majelis Ulama Indonesia (MUI), seperti fatwa tentang keha- rusan "sertifikat halal" bagi produk makanan, minuman dan kosmetik. MUI melalui Lembaga Pengkajian Pangan, Obat-Obatan dan Kosmetik (LP-POM MUI) berupaya melakukan penelitian terhadap produk makanan, minuman, obat-obatan dan kos- metik yang diproduksi oleh suatu pabrik untuk dipasarkan. Hal yang seperti ini tidak pernah ada teks nash yang menyinggungnya secara langsung. Demi kemaslahatan masya- rakat maka fatwa tersebut diterbitkan berasaskan pertimbangan maslahah mursalah .Kemudian berkaitan dengan fatwa keharaman bunga bank, juga tidak disebutkan hukumnya secara jel menetapkan bunga bank itu haram untuk mengqiyaskan kepada riba karena menurut mereka unsur tambahan yang menjadi illat haramnya riba juga terdapat pada bunga bank. ${ }^{25}$

d. Prinsip hukum Islam maslahah saat ini dapat digunakan sebagai mekanisme penyaringan etis untuk diajarkan sebagai bagian dari proses pendidikan akuntansi yang bermoral atau beretika (Rahmandan Rahim, 2012). Konsep maslahah sosial juga digunakan dalam sistem keuangan Islam saat ini khususnya dalam hal tanggung jawab social. ${ }^{26}$

Di dalam Kompilasi Hukum Islam (KHI) Inpres No. 1 Tahun 1991 dalam buku tentang Perkawinan, Bab II Pasal 2 ayat satu yakni agar terjamin ketertiban perkawinan bagi masyarakat Islam setiap perkawinan harus dicatat. Hal ini juga telah dipaparkan dalam

\footnotetext{
${ }^{23}$ Muhammad Abu Zahrah, Ushul al-Fiqh, terj. Saefullah Ma'shum. et al. Ushul Fiqih. (Jakarta: Pustaka Firdaus, 2005), h. 29-35

${ }^{24}$ Muhammad Abu Zahrah, 2005, h. 29-35

${ }^{25}$ Siti Musrofah, "Konsep Maslahah Mursalah dalam Dunia Bisnis dengan Sistem Franchise (Waralaba), Skripsi. Fakultas Syariah dan Hukum UIN Syarif Hidaya- tullah. Jakarta, h. 1- 75.

${ }^{26}$ Ismail Cebeci, (2012). "Integrating The Social Maslaha Into Islamic Finance" Accounting Research Journal. Vol. 25. Issue: h. 3, 45
} 
UU No. 1 Tahun 1974 tentang perkawinan Bab 1 pasal ayat 2 tentang tiap-tiap perkawinan dicatat menurut peraturan perundang-undangan yang berlaku. Hal ini memberikan pemahaman bahwa tujuan mencatatkan perkawinan itu untuk mencari ketertiban dan kemashlahatan. Namun peraturan tentang pencatatan tidak dikenal di zaman Nabi, sahabat dan tabi'in. Namun pencatatan itu baru dikenal di zaman modern dan di Negara-negara Eropa dan Amerika. Pencatatan perkawinan itu adalah mashlahah almursalah karena tidak ada dalil khusus yang menerangkan apakah menyuruh atau melarang. Namun pencatatan itu sesuai dengn tujuan pensyari'atan hukum yakni kemashlahatan. Masih banyak peraturan-peraturan hukum perkawina dalam, muamalah yang jelas telah dibuat dalam UU, Inpress yang tidak dielaskan secara jelas dalam Al-quran dan Al-sunnah.

\section{PENUTUP}

Dari berbagai uraian di atas dapat ditarik kesimpulan bahwa mashlahah mursalah itu adalah sesuatu yang baik menurut akal, selaras dengan tujuan syara' serta tidak ada petunjuk syara' secara khusus yang menolak atau mengakuinya. Memahami mashlahah almursalah dapat memberi kontribusi dalam menetapkan hukum ketika tidak ada dalil syari' yang menjelaskannya.

\section{DAFTAR PUSTAKA}

Thufi, al-Ta'yin Fi Syarhi al-Arba'in, (Beirut: Muassasah alRayyan, 1998).

Alim, Yusuf Hamid, Al-maqashid Al-'ammah li syari'ati Al-islamiyyah, (Riyadh: Al-ma'had Al-'alamy li al-fikr Al-islamy, 1415 H/1994 M).

Munawwir, Ahmad Warson, Kamus Arab Indonesia Terlengkap, (Surabaya: Pustaka Progressif, 1997),

Syarifuddin, Amir, Ushul Fiqh Jilid 2, (Jakarta: Kencana Prenada Media Group, 2014).

Abu Ishaq Ibrahim bin Musa Al-lakhmi Al-gharnathi Al-maliki, Al-muwafaqat fi Ushul Alushul Al-syari'ah (Beirut: Dar Al-kutb Al-islamiyyah, 2004).

Ghazali, Abu Hamid, Al-mustashfa min 'ilm Al-ushul, (Beirut: Dar Al-ma'a>rifah, 1993), jilid. 2.

Khalaf, Abdul Wahab, Ushul Fiqh, (Kairo: Dar Al-qalam, 1978).

Bisri, Cik Hasan, Model Penelitian Fiqih, Jilid I. Jakarta: Grafindo Persada, t.t.

Departemen Pendidikan dan Kebudayaan, Kamus Besar Bahasa Indonesia (Jakarta: Balai Pustaka, 1996), cet. Ke-2. 
Fauzi, Al-Maslahah al-Syar'iyah Sebagai Sumber Hukum Islam, Kajian Kitab Dawabith alMashlahah Syeh Said Ramadan Buti, “Tribakti Jurnal Pemikiran Keislaman” Vol 27 No 2 (2016).

Muhammad bin 'Ali Al-syaukani, Irsyad Al-fuhul 'ila Thaqiq min 'ilm Al-ushul, (Riyadh: Dar Al-ma'arif, 2000).

Buthi, Muhammad Sa'id Ramadhan, Dhwabith Fi Al-syaria'h Al-Islamiyyah (Beirut: Muassasah Al-risa>lah, 2001).

Nasrun, Haroen, Ushul Fiqh. (Jakarta: Logos Wacana Ilmu, 2001)

Syaikh Al-islamy 'Izz Al-din 'Abd -'aziz bin 'Abd Al-salam, Al-qawa'id anam (Damaskus : Dar Al-qalam).

Abu Ishaq Ibrahim bin Musa Al-lakhmi Al-gharnathi Al-maliki, Al-muwafaqat fi Ushul Alushul Al-syari'ah (Beirut: Dar Al-kutb Al-islamiyyah, 2004).

Alim, Yusuf Hamid, Al-maqashid Al-'ammah li syari'ati Al-islamiyyah, (Riyadh: Al-ma’had Al-'alamy li al-fikr Al-islamy, 1415 H/1994 M).

Buthi, Muhammad Sa'id Ramadhan, Dhwabith Fi Al-syaria'h Al-Islamiyyah (Beirut: Muassasah Al-risalah, 2001).

Noorwahidah, "Esensi al-mashlahah al-mursalah dalam teori istinbat hukum imam syafi'i. Syariah Jurnal Hukum Dan Pemikiran, 2014. https://doi.org/10.18592/syariah.v13i.

Syaukani, Muhammad bin 'Ali, Irsyad Al-fuhul 'ila Thaqiq min 'ilm Al-ushu>l, (Riyadh: Dar Al-ma'arif, 2000).

Khalaf, Abdul Wahab, Ushul Fiqh, (Kairo: Dar Al-qalam, 1978).

Abu Ishaq Ibrahim bin Musa Al-lakhmi Al-gharnathi Al-maliki, Al-muwafaqat fi Ushul Alushul Al-syari'ah (Beirut: Dar Al-kutb Al-islamiyyah, 2004).

Syukur, Sarmin, Sumber-sumber HukumIslam, (Surabaya: Al-Ikhlas, 1993).

Syaputra, Elvan, Faridl Noor Hilal, Muhammad Febriansyah, Issa Qaed, Muhammad Majdy Amiruddin, Muhammad Ridhwan Ab. Aziz.. "Maslahah as an Islamic Source and its Application in Financial Transactions". Journal of Research in Humanities and Social Science. Volume. 2. Issue 5, (2014).

Zahrah,Muhammad Abu, Ushul al-Fiqh, terj. Saefullah Ma'shum. et.al. Ushul Fiqih. (Jakarta: Pustaka Firdaus, 2005)

Ismail Cebeci, (2012). Integrating The Social Maslaha Into Islamic Finance. Accounting Research Journal. (Vol. 25. Issue: 3, 45, 2012) 